\title{
Dynamical Outlines of the Rainfall Variability and the ITCZ Role over the West Sahel
}

\author{
Paulo Sérgio Lucio ${ }^{1,2}$, Luiz Carlos Baldicero Molion ${ }^{3}$, Cati Elisa de Avila Valadão², \\ Fábio Cunha Conde ${ }^{4}$, Andrea Malheiro Ramos ${ }^{1,4}$, Maria Luciene Dias de Melo ${ }^{3}$ \\ ${ }^{1}$ Centro de Geofísica de Évora (CGE), Évora, Portugal \\ ${ }^{2}$ Universidade Federal do Rio Grande do Norte (UFRN), Centro de Ciências Exatas e da Terra \\ (CCET), Natal, Brazil \\ ${ }^{3}$ Universidade Federal de Alagoas (UFAL), Alagoas, Brazil \\ ${ }^{4}$ Instituto Nacional de Meteorologia (INMET), Brasília, Brazil \\ Email: pslucio@uevora.pt,pslucio@ccet.ufrn.br, molion@radar.ufal.br, cati.valadao@gmail.com, \\ fabio.conde@inmet.gov.br, andrea.ramos@inmet.gov.br, ludmelo@gmail.com
}

Received November 29, 2011; revised February 10, 2012; accepted March 3, 2012

\begin{abstract}
This article evaluated the plausible causes of floods and droughts, the relative roles of large-scale climate variability in regional environmental trends, and the prospects for the future of the semiarid Sahel region in the context of periodic climate change. It is pointed out that the most significant rainfall climatological changes in the Sahel probably occurred between 1950 and 1980 with the decrease of the annual rainfall, a very high deficit (about 70\%) over the whole region. The last three decades considered in this research (1981-2010) showed some improvement. The more humid conditions were from the last decade 2001 to 2010. One of the most significant climatic variations has been the persistent rainfall decline in the Sahel since late 1960s. Remarkable latitudinal shift of ITF mean position towards the South generated an overall reduction of annual rainfall. Basically, in this manuscript one analyzes the dynamical features on rainfall time series and the association of the cyclic periods with teleconnections under the hypothesis that no alteration has occurred. The results supply a reliable base to develop a methodology for medium to long-term seasonal forecast.
\end{abstract}

Keywords: Climate Variability; Trend Analysis; Empirical SPI; BEST Index; PDO Index

\section{Introduction}

The semiarid Sahel region $\left(10^{\circ} \mathrm{N}-20^{\circ} \mathrm{N}\right.$ and $18^{\circ} \mathrm{W}-20^{\circ} \mathrm{E}$, $c f$. Figure 1) experiences a high degree of climatic variability. Rainfall events have been repetitive, with extending dry and wet episodes, which could be related to the Sahara "retreating" or "advancing". The Sahel exhibits quasi-regular low-frequency modes of precipitation variability on both interannual and intraseasonal time scales. In the 1970s and 1980s it experienced repeated, devastating droughts, most notably in 1972 to 1973 and in 1982 to 1984 . Since then, scientists have been debating whether the cause for this pronounced climatic shift was anthropogenic in nature, that is, whether desertification, forced by the increasing pressure of population growth on the environment, was starting to have an impact on the regional climate [1], or whether the recurrent droughts were related to the slower, decadal time scales of oceanic variability $[2,3]$.

The drying trend in the semiarid Sahel was attributed to warmer-than-average low-latitude waters around Africa [4], which, by favoring the establishment of deep convection over the ocean, weaken the continental conver- gence associated with the monsoon and engender widespread drought over the West Africa. Effectively, the relationship between rainfall and desert margin advances or retreats brings into focus questions regarding the interactions of global change dynamics with desertification processes. The fluctuation in the size of the Sahara Desert shows a linear inverse relationship between rainfall and expansion of the desert's southern margin [5]. There is a vast literature available on this subject.

As [6] point out that not all regions of the Sahel have experienced a synchronous and systematic reduction in rainfall, and that agricultural production in the Sahelian nations has increased over the course of the period generally characterized as dry. Indeed, studies have identified different regions of coherent rainfall (seasonal variability) within the Sahelian zone, and different areas are described by different, and sometimes conflicting, anomaly patterns.

Learning about the rainfall variability and the Intertropical Convergence Zone (ITCZ) role over the west Sahel is significant since in this region (cf. [7]): 1) The ITCZ itself produces large convective available potential 


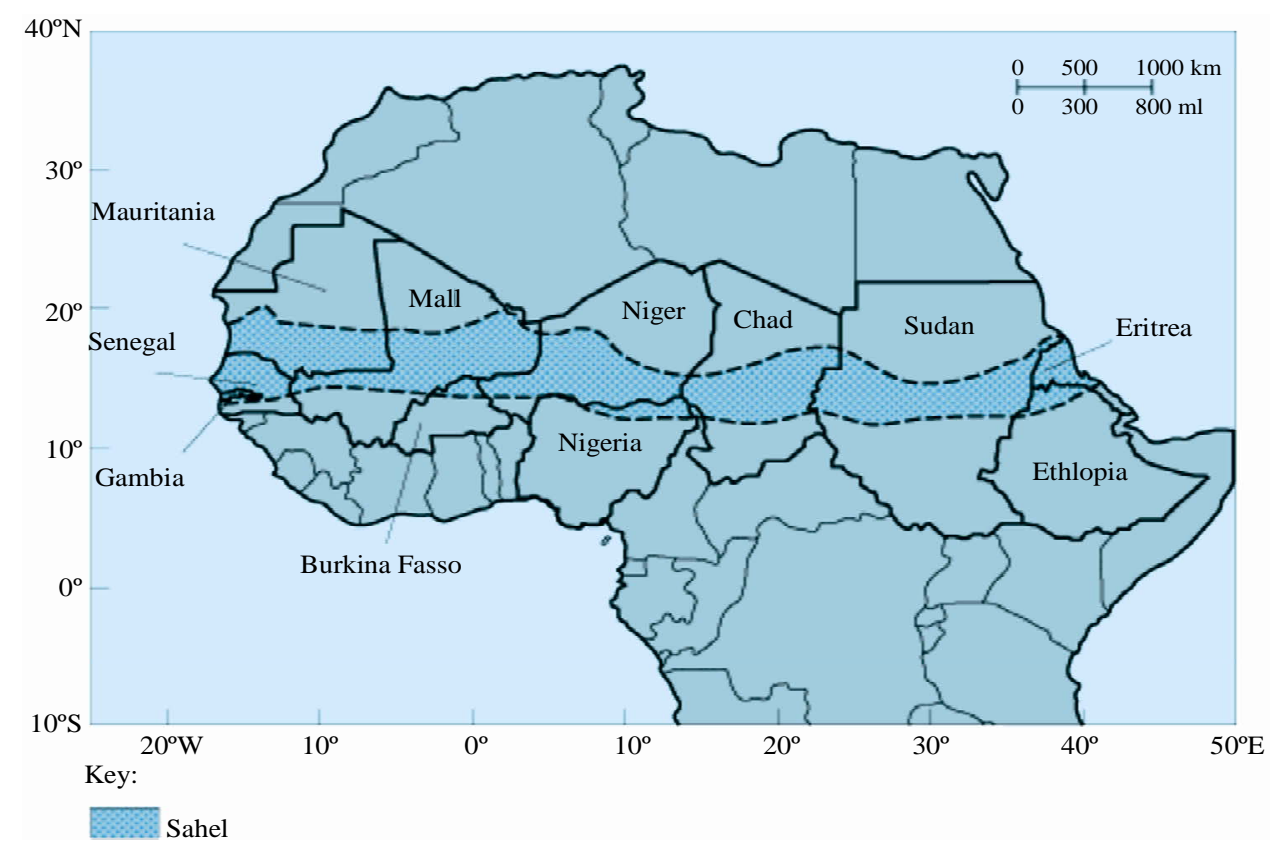

Figure 1. Location of the Sahel. The Sahelian countries are named (Source: http://accessscience.com/content/Sahel/800300).

energy that generates deep convection; 2) The abundant water vapor within the ITCZ is maintained by horizontal moisture flux; 3) Outside but near the ITCZ, shallow convection exists and may act to pre-moisten deep convection in spring and autumn; 4) The seasonal change of the ITCZ is preceded by that of the vertical moist instability in the lower free atmosphere caused by the seasonal change in insolation.

The aim of this manuscript is to further investigate rainfall relationships, assessing the relative role of largescale climate variability in regional environmental trends, the prospects for the future of the semiarid Sahel region in the context of cyclic climate change, and the role of Tropical Atlantic and South Atlantic Ocean variability in controlling the Sahel rainfall. It is also analyzed the relationship between the movement of the limits of the Sahara Desert borders with the low frequency variability of the General Circulation of the Atmosphere (GCA) patterns, forecasting the progress and retreat of the Saharan desert, detecting structural changes, characterized by a shift in persistence of the atmospheric variables time series, particularly rainfall, in the attempt to contribute to the understanding its advance and retreat.

The results of the analysis of the GCA pattern relationships, particularly those related to the continental ITCZ may be helpful to forecast the advance and retreat of the Sahara Desert and to detect structural changes, characterized by the cyclic alterations along decadal timescale. Previously [8,9] have analyzed the relationships, where the temporal characteristics of the series, such as variance, are evaluated using principal components regression. As mentioned by Fred Pearce at the 18/Sep/
2002 NewScientist issue: "It is worthwhile to remark that desertification is still often viewed as an irreversible process triggered by a deadly combination of declining rainfall and destructive farming methods. There is also a strong confusion over why the Sahel is becoming green. Scientists believe the main reason is increased rainfall since the great droughts of the early 1970s and 1980s. But farmers have also been adopting better methods of keeping soil and water on their land."

\section{Material}

In this study, for the analysis and characterization of the precipitation system, the observed data of the World Monthly Surface Station Climatology (WMSSC) were used, giving larger focus to the periods in which were observed the northward shift in the Sahara/Sahel boundary [10]. The dataset is supplied by the Joint Institute for the Study of the Atmosphere and Ocean (JISAO) that fosters research collaboration between NOAA and the University of Washington, for 14 stations of the 6 countries of the area of West Africa Sahel, whose coordinates are represented in the Table 1.

The period from 1950 to 2010 was analyzed-1950 to 2000 from the JISAO dataset and 2001 to 2010 from the National Climatic Data Center (NCDC) dataset. This period was chosen due to well-documented shifts in rainfall climate on a decadal timescale in the West African region during this time. To deal with missing data problem we applied a multiple imputation technique, the Multivariate Imputation by Chained Equations (MICE) from $\mathrm{R}$ [11]. MICE (the current version is MICE V2.7 is de- 
Table 1. The rain gauge West Sahel Africa stations (19502000). The time series data credit: JISAO climate data archive. http://tao.atmos.washington.edu/data_sets/sahel

\begin{tabular}{lll}
\hline & WMO ID & Station Location \\
\hline 1 & 610360 & TILLABERY-Niger $\left(14.2^{\circ} \mathrm{N}, 1.5^{\circ} \mathrm{E}\right)$ \\
2 & 610430 & TAHOUA-Niger $\left(14.9^{\circ} \mathrm{N}, 5.3^{\circ} \mathrm{E}\right)$ \\
3 & 610800 & MARADI-Niger $\left(13.5^{\circ} \mathrm{N}, 7.1^{\circ} \mathrm{E}\right)$ \\
4 & 612260 & GAO-Mali $\left(16.3^{\circ} \mathrm{N}, 0.1^{\circ} \mathrm{W}\right)$ \\
5 & 612700 & KITA-Mali $\left(13.1^{\circ} \mathrm{N}, 9.5^{\circ} \mathrm{W}\right)$ \\
6 & 612720 & SEGOU-Mali $\left(13.4^{\circ} \mathrm{N}, 6.2^{\circ} \mathrm{W}\right)$ \\
7 & 612930 & KOUTIALA-Mali $\left(12.4^{\circ} \mathrm{N}, 5.5^{\circ} \mathrm{W}\right)$ \\
8 & 614980 & KIFFA-Mauritania $\left(16.6^{\circ} \mathrm{N}, 11.4^{\circ} \mathrm{W}\right)$ \\
9 & 616410 & DAKAR-Senegal $\left(14.7^{\circ} \mathrm{N}, 17.5^{\circ} \mathrm{W}\right)$ \\
10 & 616540 & THIES-Senegal $\left(14.8^{\circ} \mathrm{N}, 17.0^{\circ} \mathrm{W}\right)$ \\
11 & 616660 & DIOURBEL-Senegal $\left(14.8^{\circ} \mathrm{N}, 6.3^{\circ} \mathrm{W}\right)$ \\
12 & 653060 & KANDI-Benin $\left(11.1^{\circ} \mathrm{N}, 2.9^{\circ} \mathrm{E}\right)$ \\
13 & 653190 & NATITINGUE-Benin $\left(10.3^{\circ} \mathrm{N}, 1.4^{\circ} \mathrm{E}\right)$ \\
14 & 655020 & OUGIHOUA-Burkina Faso $\left(13.6^{\circ} \mathrm{N}, 2.4^{\circ} \mathrm{W}\right)$ \\
\hline
\end{tabular}

scribed in [12]) is an R package implementing multiple imputation of incomplete multivariate data according the principle of Fully Conditional Specification (FCS). MICE consists of a set of flexible tools for creating multiple imputations and for the analysis of multiply imputed data sets [12], as cited in [13] and Van Buuren et al. [14], have shown that if the method to create imputations is "proper", then the resulting inferences will be statistically valid.

In the analyses, the dataset of overall concerned variables: sea level pressure (SLP), sea surface temperature anomaly (SSTA), zonal (u) and meridional (v) wind components, outgoing long-wave radiation (OLR), omega, and Bivariate ENSO time series (BEST) index; were obtained from the Earth System Research Laboratory, Physical Sciences Division (ESRL/PSD), available at: http://www.esrl.noaa.gov/psd/data. The sea surface temperature anomaly (SSTA) was analyzed over an area near Africa $\left(40^{\circ} \mathrm{S}-50^{\circ} \mathrm{N} ; 50^{\circ} \mathrm{W}-80^{\circ} \mathrm{E}\right)$. In addition, PDO index obtained from the University of Washington-Department of Atmospheric Sciences was also used (http://jisao.washington.edu/pdo/PDO.latest).

\section{ITCZ Variability: Dynamical Evaluation}

The ITCZ, or the intertropical discontinuity, is the most prominent meteorological phenomenon of the tropics and appears at the ascending branch of atmospheric Hadley cells. Previous studies have described the ITCZ as char- acterized by low pressure, maximum surface temperature, high cloudiness, rainfall, and trade wind convergence and confluence (e.g., $[15,16])$. Nevertheless, uncertainty remains in our understanding of the ITCZ, especially regarding its formation mechanisms ( $c f .[15,17])$.

The characteristics of the ITCZ over Eastern Atlantic and over the African continent differ considerably. Over the continent, for instance, the heat low of the equatorial trough is more intense and the thermodynamic properties of the air either side of the flow discontinuity, especially dew point, are more pronounced. The Atlantic ITCZ originates from the convergence of the Northeastern and Southeastern trades, flowing out of the subtropical anticyclones towards the equator in both hemispheres, and it moves north-south about the equatorial belt, roughly between $3^{\circ} \mathrm{S}$ and $14^{\circ} \mathrm{N}$ in the course of the year. The continental ITCZ, on the other hand, results from the convergence of continental northerly flow with a southwesterly flow, that starts off the South Atlantic subtropical high pressure system. As the flow crosses the equator, it is deflected to the right, becoming southwesterly winds and carrying moisture into the continent. Because of its distinct genesis, French meteorologists named the continenttal convergence zone the Intertropical Front (ITF)-the interface or transition zone occurring within the equatorial trough between the Northern and Southern hemispheres. It is also known as equatorial front or tropical front. The low pressure and the embedded flow discontinuity associated to the ITF undergo a larger latitudinal displacement during the annual cycle, reaching its northernmost position, about $20^{\circ} \mathrm{N}$, during the northern summer.

The ITF is also a fundamental feature of the atmospheric circulation over West Africa. It separates the wedge of warm moist southwesterly monsoon flow off the tropical Atlantic from much hotter and very dry northeasterly wind from the Sahara Desert [18]. At the surface, the wind direction discontinuity is characterized by pronounced temperature and humidity gradients that migrate seasonally northward then southward, lagging somewhat the zenith angle of the sun in the northern tropics. Between the surface and about $700 \mathrm{hPa}$, the ITF slopes upward to the south at inclinations between $1: 100$ and $1: 400$ [19] and is the upper boundary of the meridionally migrating wedge of monsoon air. The coincident zones of maximum horizontal velocity, moisture convergence and rainfall that are the West African manifestations of ITCZ occur a few hundred kilometers south of the ITF, where the monsoon wedge is deeper.

Global climate variability is intimately linked to the strength of the Asian Monsoon circulation, which is coupled with the SST patterns of North Pacific Ocean. This, in turn, is submitted to low frequency, as such as the Pacific Decadal Oscillation (PDO) and high frequency, like 
the El Nino Southern Oscillation (ENSO) shifts. In the low frequency mode, when the North Pacific is warmer (colder) than normal in the extratropics (tropics), the monsoon circulation is stronger in summer and NE trades are stronger in winter, a positive feedback that maintain the tropical Pacific cold. The cold Pacific SST pattern may be responsible for the displacement of the North (South) Atlantic subtropical high pressure center to Southwest (Northwest) of its mean position approaching the equator. This displacement away from the continent reduces the pressure over Sahel and increases the north-south pressure gradient, strengthening the African monsoon.

The ENSO phenomena modulate the interannual variability over Sahel, as seen in El Niño years such as 1972 -1973 and 1986-1987. However, both El Niño (EN) and La Niña (LN) events may have similar impact on rainfall, depending on the PDO phase. For instance, EN events of the PDO cold (warm) phase produced wet (dry) events in general. The Atlantic Ocean plays a secondary role in modulating rainfall, modifying ENSO events. For instance, 1984 LN was a dry event (colder SST) as opposed to $1978 \mathrm{EN}$ that was a wet event (colder SST) in PDO warm phase. This regional control exerted by the Atlantic dictates the displacement of ITF in some years.

The Western Africa as well as close regions can be less sensitive to the ENSO events compared with other mid-latitude areas. However, exceptions exist for the phases of warm and intense ENSO, when Western Africa can suffer relative climatic impacts indicating drastic reduction of the southwest monsoon precipitation amount. There is a significant correlation between the LN predominance (EN) and the increase (decrease) trend of precipitation. In the period in which LN prevails, there is a positive tendency of the precipitation that reveals larger precipitation. In the period of EN predominance, there is a negative tendency, decreasing the precipitation amount. During the LN, the East-West circulation is stronger than the normal; there is a strong ascending motion over West Africa that can intensify the convective activity producing rainfall above the average.

It is arguable that the Sahel is the only one of the world's dry land regions to have experienced a signifycant change in climate resulting in increased aridity this century. Many authors have described the period since the late 1960's as representing a desiccation, that is, a phase characterized by persistent drought. As [20] describes this recent desiccation as contributing to an equivalent mean linear trend amounting to a $21 \%$ decrease in rainfall over the twentieth century. The downward trend in rainfall did not begin at the start of the dry episode; aggregated Sahel rainfall systematically declines from 1954. Dry episodes occurred in the 1910s and 1940s, but were of relatively short duration. The 1930s and 1950s were dominated almost entirely by wet years, with no significant rainfall deficits (there were no rainfall deficit years in the 1950s and there are no statistical significance indicating a behavior below average). In the 20th century, 1950 and 1954 were the wettest years.

\section{The Sahel Rainfall Variability: Climatological Assessment}

In this study there is a focus on the seasonal variation in the geographical position of the ITCZ, even though it is well-known that the ITCZ is sensitive to local scale processes such as regional circulation and air-surface interactions. The climate diagnostics were made considering the interannual and interdecadal timescales. In addition, considering the cluster analyses, it is evident that the Sahel climate is not uniform and presents regional to local differences. The rainfall regime can be stochasticcally subdivided into three distinct areas (northern, southern and central), within which observed monthly rainfall time series are very similar one to another.

In a previous study, using the same time series dataset from the West Sahel region, [9] found strong empirical evidence of seasonality. They defined three precipitation regimes: Wet Season $\underline{\mathbf{S 1}}$ (Jul.-Aug.-Sep.), Transition Season $\underline{\mathbf{S} 2}$ (Jun. and Oct.) and Dry Season $\underline{\mathbf{S} 3}$ (Nov.-Dec.Jan.-Feb.-Mar.-Apr.-May). Also, the temporal characteristics of the series, such as variance, were evaluated using principal components regression. The Principal Component Analysis ${ }^{1}$ was used to understand the underlying data structure and to form a smaller number of uncorrelated variables. The rainy regime corresponds to the period in that ITCZ reaches its northernmost position in its movement towards the north and the activity of the monsoon is more intense. During the dry regime, the ITCZ migrates towards the South.

Regarding the monthly rainfall, the evidence of sea-

\footnotetext{
${ }^{1}$ Concerning the West Sahel Season S1, the first principal component explained (captured) $41.8 \%$ of the total variability. The second principal component showed a variance accounting for $14.6 \%$ of the data variability. Together, the first two principal components captured $56.4 \%$ of the total variability. Regarding the West Sahel Season $\underline{\mathbf{2}}$, the first principal component had a variance accounted for $39.1 \%$ of the total, whereas the second principal component had variance accounted for $18.8 \%$ of the data variability. Together, the first two principal components represented $57.9 \%$ of the total variability. For the West Sahel Season $\underline{\mathbf{S}}$, the evaluation of the first principal component resulted in a variance accounted for $40.0 \%$ of the total variance, and the second principal component had a variance of 2.43 and accounted for $17.4 \%$ of the data variability. Together, the first two principal components represented $57.4 \%$ of the total. The interannual difference of the rainfall regimes between the two succeeding periods, 1951-1975 being wet, and 1976-2000 being dry was $180 \mathrm{~mm} / \mathrm{yr}$. It appears that, in the intraseazonal timescale, the rainfall deficit of the dry period resulted primarily from the reduction of the number of events occurring during the core of the first rainy season for regions extending southward to $9^{\circ} \mathrm{N}-10^{\circ} \mathrm{N}$. In the southern areas, the dry period was characterized by a shift in time of the second rainy season. All these characteristics have strong implications in terms of agricultural and water resources management.
} 
sonality is remarkable, defining the important contribution of July, August and September for the rainy periods. Seasonality explains the major part of the total variance. In [9], it was shown that there are primarily three spatial modes of rainfall variability in the region and these differ with respect to the part of the rainy season in which they are most important and to what extent they describe high and low-frequency components of the variability. That study also defined three broad homogeneous sectors and demonstrates that the characteristics of rainfall variability in these sectors differ markedly-three spatial networks were constructed for analyzing rainfall variability over West Sahel Africa. For each candidate area the set of annual networks was stored for the period of 1950-2010, reflecting the spatiotemporal variability on the West Sahel African region.

Taking into account these concerns, [9] have suggested to combine the rainfall in three groups, classifying similar rainfall regimes (defining similar spatiotemporal rainfall regimes). The final partition is given by: (스) Tillabery, Tahoua, Maradi, Gao and Ougihoua $(\rho=89 \%)$; (2) Kita, Segou, Koutiala, Kandi and Natitingue $(\rho=$ 88\%); ( $\underline{\mathbf{R 3}}$ ) Kiffa, Dakar, Thies and Diourbel ( $\rho=87 \%)$. These connections may be used to verifying if monthly total precipitation in Mali (Senegal) tends to indicate rainfall monthly total in Burkina Faso (Mauritania), for instance. These variables may contain similar information and be accurately combined.

\section{The Standartized Precipitation Index (SPI)}

The understanding that a deficit of precipitation has different impacts on groundwater, reservoir storage, soil moisture, [21] developed the Standardized Precipitation Index (SPI). The SPI is designed to quantify the precipitation deficit for multiple time scales. These time scales reflect the impact of drought on the availability of the different water resources. Soil moisture conditions respond to precipitation anomalies on a relatively short scale. Groundwater, streamflow, and reservoir storage reflect the longer-term precipitation anomalies. The SPI is a relatively new drought index based only on precipitation and can be used to monitor conditions on a variety of time scales. This temporal flexibility allows the SPI to be useful in both short-term agricultural and long-term hydrological applications.

The SPI calculation for any location is based on the long-term precipitation record for a desired period. This long-term record is fitted to a probability distribution, which is then transformed into a normal distribution so that the mean SPI for the location and desired period is zero. Positive SPI values indicate greater than median precipitation, and negative values indicate less than median precipitation.
In [21], it was used the classification system shown in the SPI values table to define drought intensities resulting from the SPI, defining the criteria for a drought event for any of the time scales. A drought event can occur any time while the SPI is continuously negative and reaches an intensity lower than -1.0 . The event ends when the SPI becomes positive. Each drought event, therefore, has a duration defined by its beginning and end and an intensity for each month that the event continues.

Based on the analyses of stations across the Western Sahel, Figure 2 shows that the SPI is in mild to moderate drought from 1965 until 1980 and after 1990-1995, in severe to extreme drought between 1980 and 1985. Because the SPI is standardized, these percentages are expected from a normal distribution of the SPI. The $2.7 \%$ of SPI values within the "Extreme Drought" category is a percentage that is typically expected for an "extreme" event. The standardization allows the SPI to determine the rarity of a current drought, as well as the probability of the rainfall necessary to end the current drought [21].

Analysing the graphics (Figure 2) together, it allows for tracking both the stochastic process level and their variations at the same time, as well as detect the occurrence of special time series structures such as trends or breaks. Structural change-points ${ }^{2}$ can be easily observed taking place during 1965, from 1980 and 1995, which can be associated to the PDO. The PDO cold and warm phases were considered for the purpose of this diagnostics.

To verify the consistency of the three selected cells of the network, it was established the relationship between rainfall related variables, particularly SLP, OLR and omega for the dry period (1983, highly negative SPI) and for the wet period (1975, highly positive SPI).

\section{Results and Discussion}

The rainfall anomalies recorded during the period of study (1950-2004) are linked to the variability of the southwestern monsoon of the West Africa. For dry years, it was noticed a delay of the southwestern monsoon in moving northward, as well as other atmospheric structures such as the FIT, the centers of the Azores and Santa Helena Atlantic anticyclones and anomalous cooling of the northwestern sea surface off West Africa [15].

In the period from 1950 to 1976 (PDO cold phase), there was a higher frequency of La Niña events, while from 1976 to 2000, the El Niño (strong) events predominated (Figure 3). The correlation between La Niña (El Niño) presence and the positive (negative) anomaly of precipitation over the Sahel region was evident-atmospheric

\footnotetext{
${ }^{2}$ Note that the difficulty in the detection of structural change-point in time series is mainly due to the homogeneity of observed meteorological time series, which is often corrupted by methodological and microenvironmental changes that might affect the reliability of climate variability investigations [21].
} 


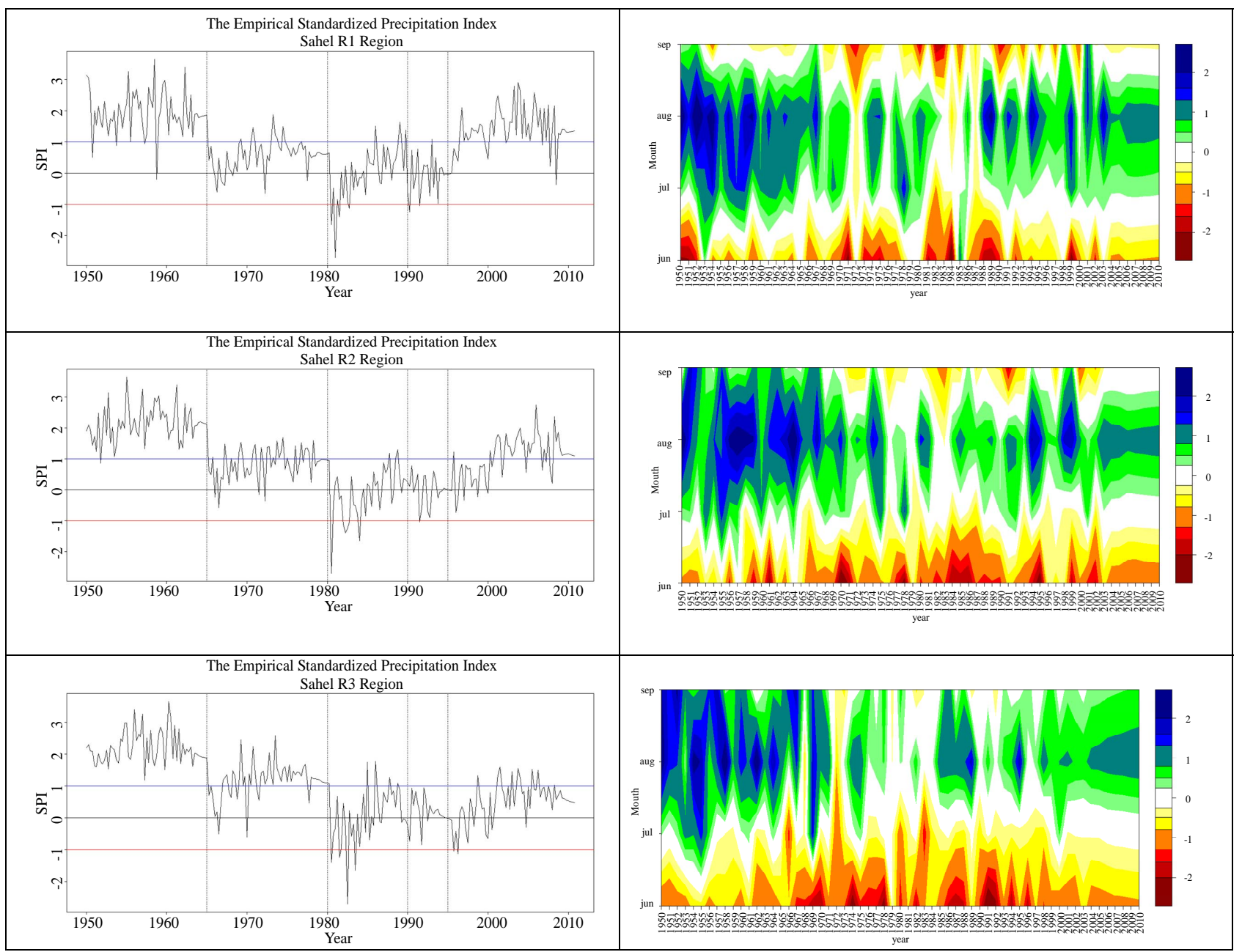

Figure 2. The 1D time series representation of the empirical SPI for the Sahel R1, R2 and R3 Regions (left), and the corresponding schematic pseudo-3D graph of the empirical SPI (right).

teleconnections exists, particularly in the fields of atmospheric pressure, that produce climatic anomalies in so far away areas of the phenomena that gave them origin.

The rainfall tendency for the three seasons (dry, wet and transition) reveals that, for the studied stations, the dry season did not record tendency of precipitation variation, while the transition and rainy seasons presented weak negative tendency, and strong and significant negative, respectively. Figure 4 illustrates the SPI-based annual rainfall for all meteorological stations in the West Sahel Africa (1950-2010), where structural changepoints can be easily observed of about 1965, 1980 and 1995. The change point problem in time series is to detecting that a structure of generating data has changed at some time point by some cause. Figure 3(a) illustrates the PDO $^{3}$ index (1950-2010).

Running means of the Sahel rainfall neatly separates

${ }^{3}$ The PDO is the leading Principal Component of monthly SST anomalies in the North Pacific Ocean, poleward of $20 \mathrm{~N}^{\circ}(c f .[22,23])$. interdecadal variability, with a negative trend in Sahel rainfall (hereafter referred to as the low-frequency component of Sahel rainfall variability), from the interannual variability (hereafter referred to as its high-frequency component), associated with PDO warm/cold phases and ENSO, respectively. The role of PDO in Sahel's climate decadal variability is arguable but the role of ENSO in the interannual timescale is undeniable, as seen through the existent relationship between the high-frequency components of the Sahel rainfall with SST anomalies of the oceans surrounding Africa, which are responsible for the low frequency variability ( $c f$. [24-29]). It seems that the warming trend in the equatorial Indian Ocean may have favored the enhancement of deep convection over the ocean and intensified the subsidence over Western Africa and weakened the monsoon. That is, the Western African winds weakened and the layer of moisture transport into the continent had a reduction in of about 1 $\mathrm{km}$ in thickness, thus reducing the moisture transport and rainfall over the area. Notable features of the atmospheric 
The Pacific Decadal Oscillation Index

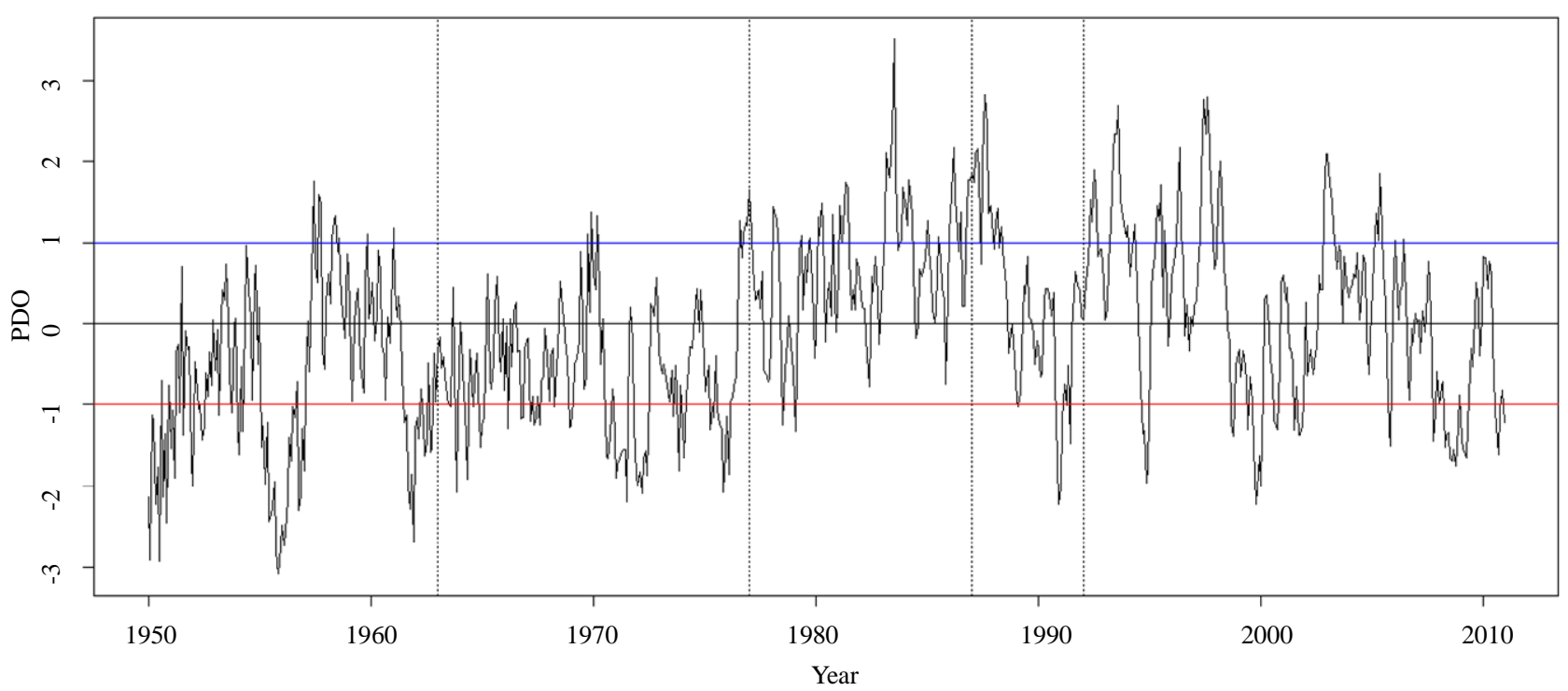

(a)

The Bivariate ENSO Time Series Index

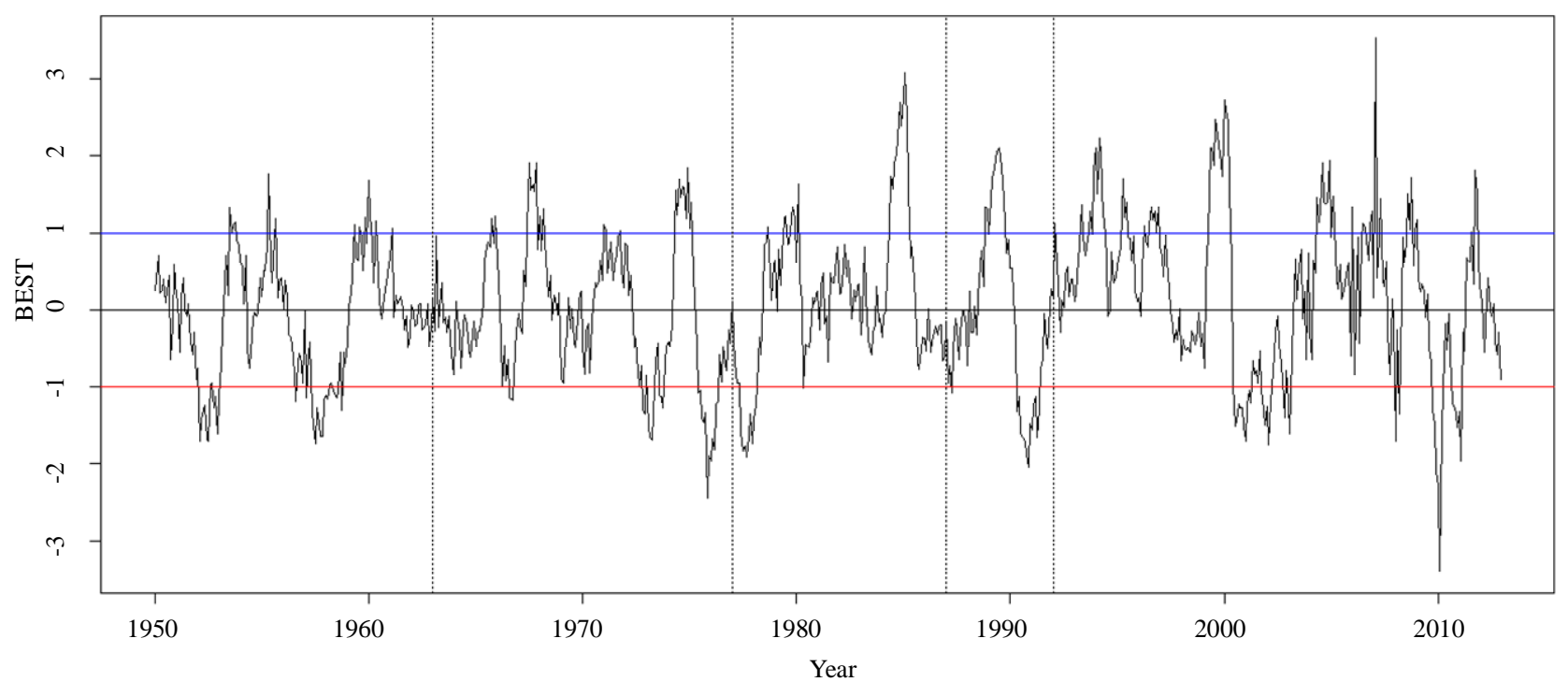

(b)

Figure 3. (a) Chronological time series of the Pacific Decadal Oscillation (PDO) index (1950-2010). Structural change period can be easily detected between 1972 and 1986. The PDO data set is available at: http://jisao.washington.edu/pdo/PDO.latest; (b) The monthly Bivariate ENSO Time Series (BEST) Index. The ENSO data set is available at: http://www.esrl.noaa.gov/psd/data/correlation/censo.data

response are: 1) Tropospheric warming centered over the convection region in the equatorial Indian Ocean and a weaker Tropical Easterly Jet; 2) Rainfall anomalies of opposite signs over the Sahel and over the equatorial Indian Ocean; 3) Equatorial westerly wind anomalies to the west of the equatorial Indian Ocean SST anomalies and northeasterly winds anomalies over Africa.

The relationship between the variables SLP, OLR, omega and rainfall was explored. In order to better assess the FIT variability during the dry and wet events, two contrasting years were analyzed: the year 1975, a wet La Niña year during the PDO cold phase, and the year 1983, a dry El Niño year during the PDO warm phase. In Figure 5, the mean rainfall, in $\mathrm{cm}$ per month $(\mathrm{cm} / \mathrm{mo})$, for the rainy season (July to September) for the two selected years is shown, together with their rainfall differences 


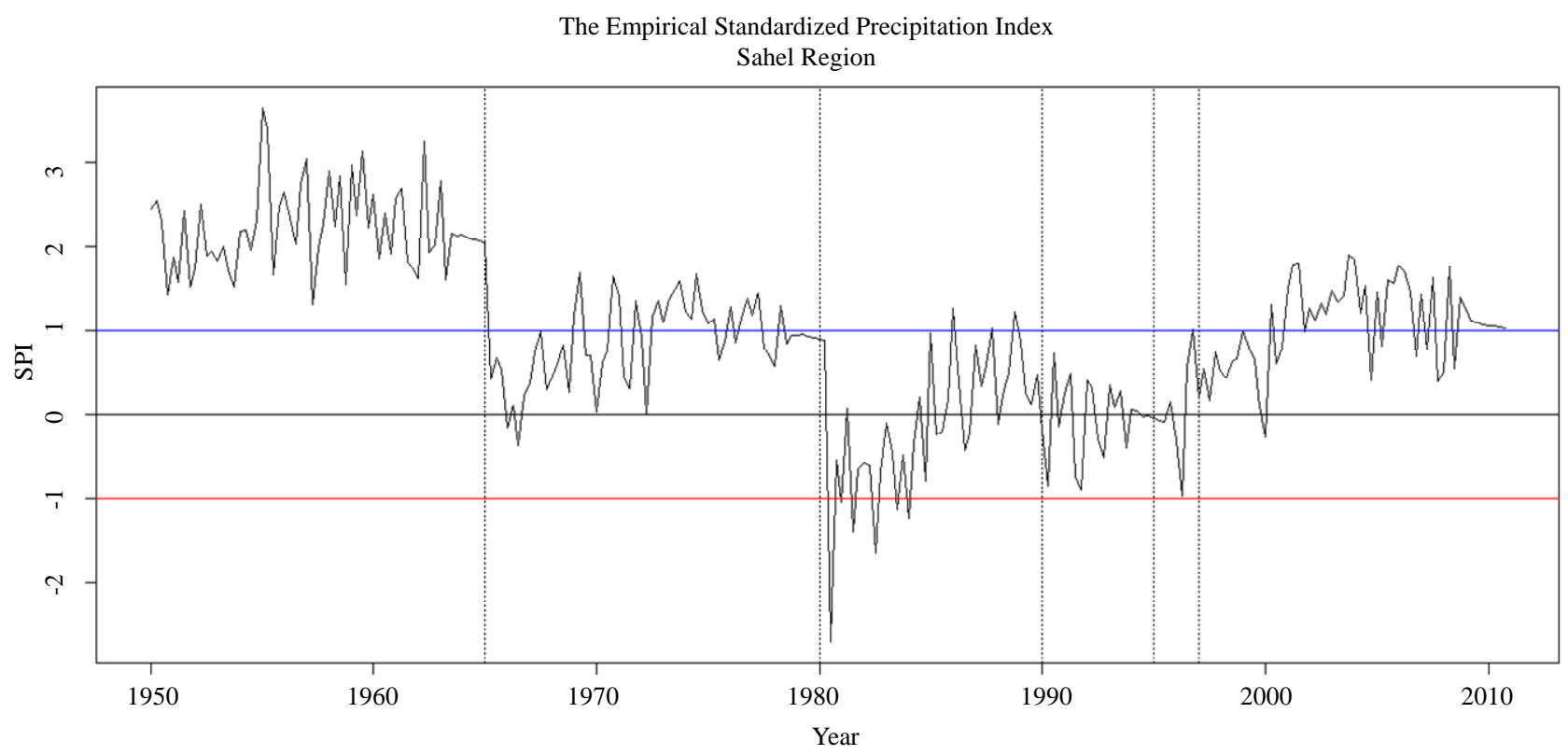

(a)

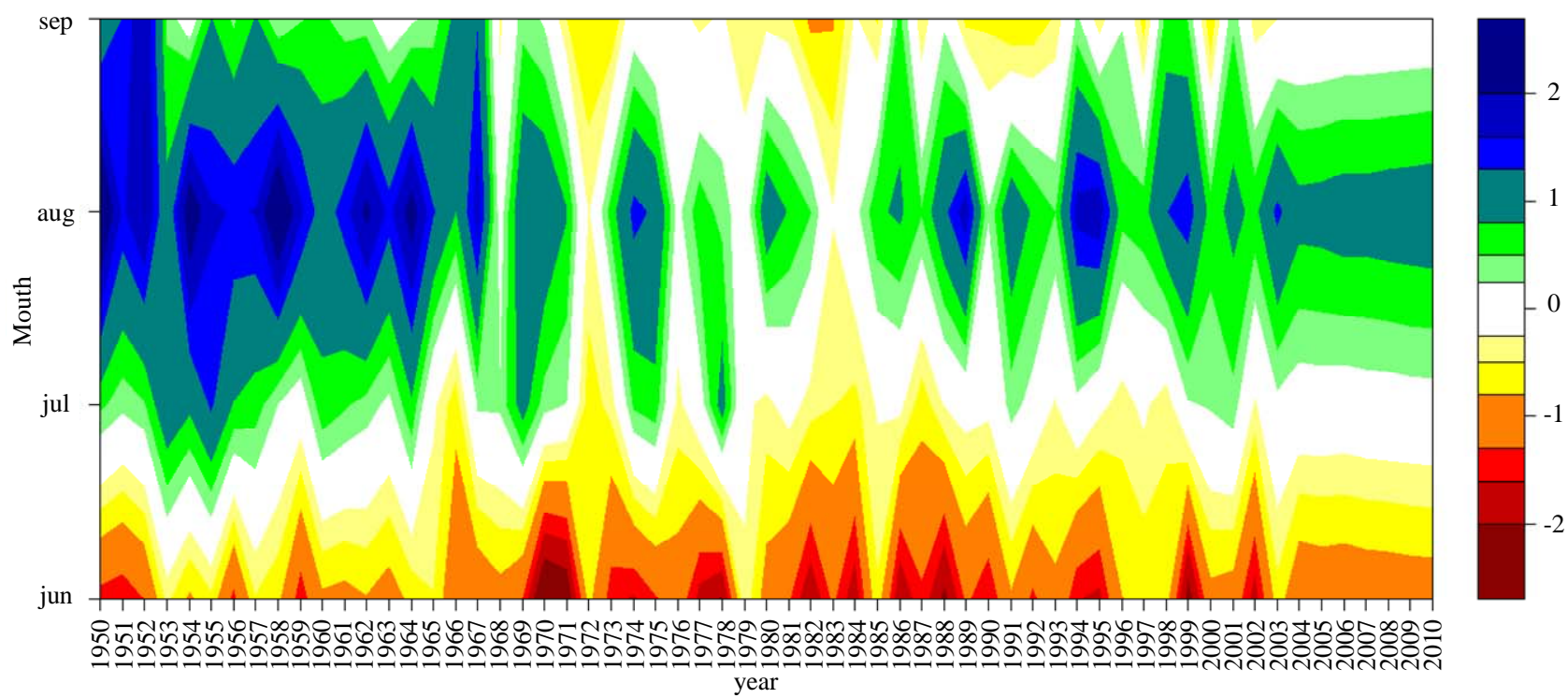

(b)

Figure 4. (a) the 1D time series representation of the empirical SPI-the trend analysis of the SPI-based annual rainfall for the whole meteorological stations on the West Sahel Africa (1950-2010). Structural change-points can be easily observed of about 1965, 1980 and 1995; and (b) the schematic pseudo-3D graph of the empirical SPI for the Sahel Region.

(1975 minus 1983). The data used to draw these figures is the University of Delaware $0.5 \times 0.5$ gridded data set, available, for instance, in the ESRL/PSD/NOAA site. As opposed to 1983 dry year, most of the Sahel had rainfall mean values exceeded $20 \mathrm{~cm} / \mathrm{mo}$ in 1975, with highest total over $80 \mathrm{~cm} / \mathrm{mo}$ along the western coast $5^{\circ} \mathrm{N}-15^{\circ} \mathrm{N}$. Differences in excess of $20 \mathrm{~cm} / \mathrm{mo}, 1975$ minus 1983 rainy seasons, were found over the same area (Figure 5(c)).

An inspection of the SLP fields showed that the 1975 rainy season was characterized by negative anomalies extending for almost the whole Sahel, as opposed to the 1983 rainy season, when the negative SLP anomalies were found farther north of the studied area. Hovmöller diagrams of SLP daily anomalies (in $\mathrm{Pa}$ ), with respect the 1981-2010 mean and averaged for the longitudinal band $5^{\circ} \mathrm{W}-15^{\circ} \mathrm{W}$ (Western Sahel), were elaborated (Figure 6) for (a) the 1975 wet year and (b) for 1983 the dry year. This diagram shows the latitudinal displacement of the anomalies with respect to time (vertical axis) from 


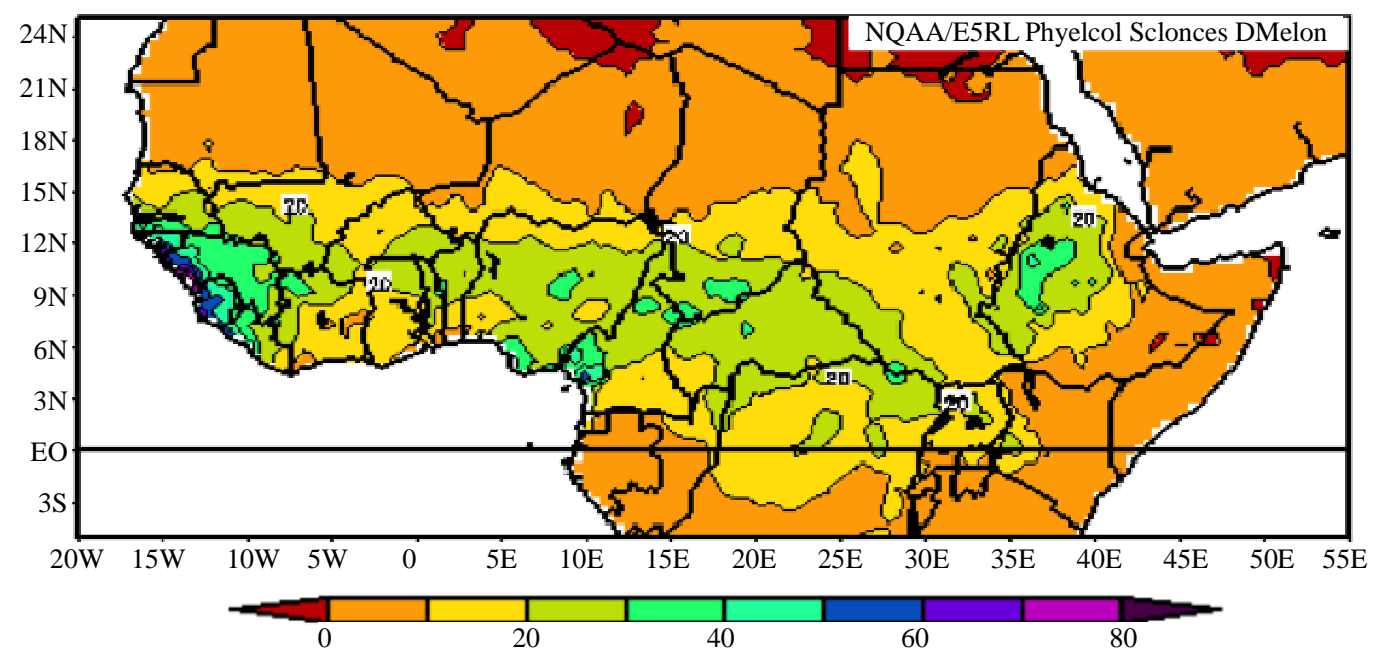

(a)

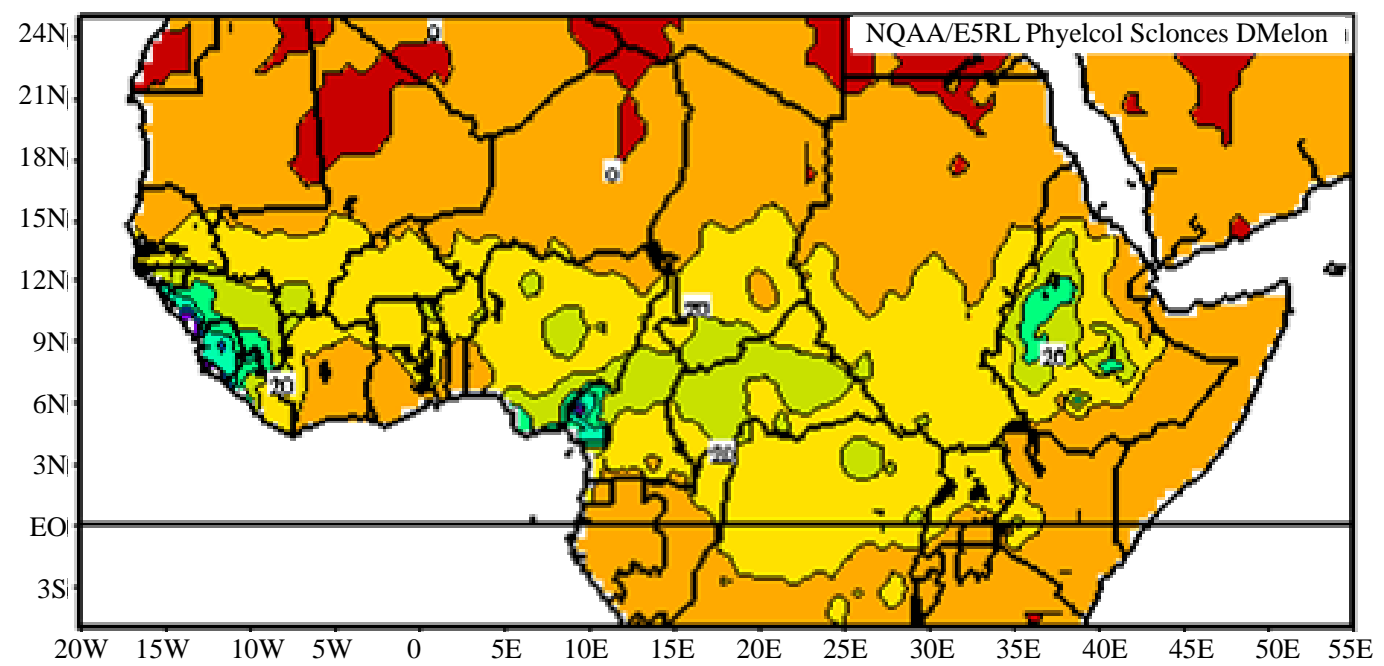

(b)

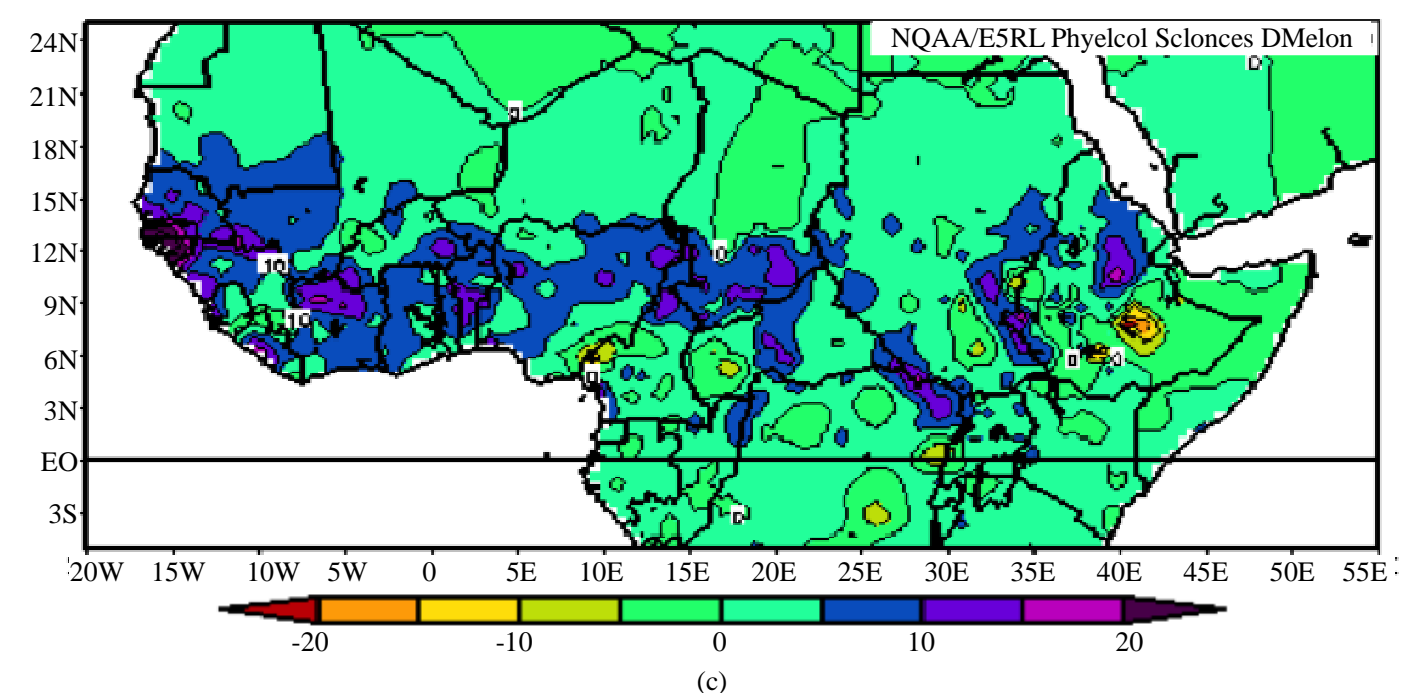

Figure 5. Mean rainfall over Sahel (in cm/mo) for the (a) 1975 wet year; (b) 1983 dry year; and (c) difference 1975 minus 1983 rainy season (Data source: NOAA/ESRL/PSD). 


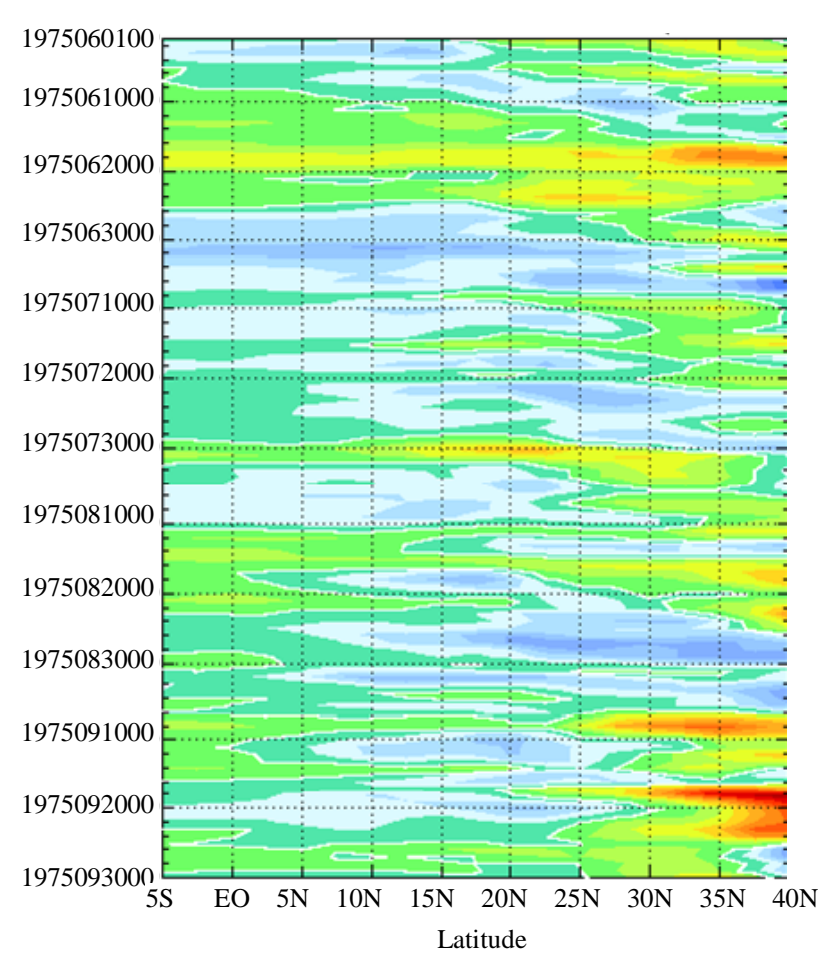

(a)

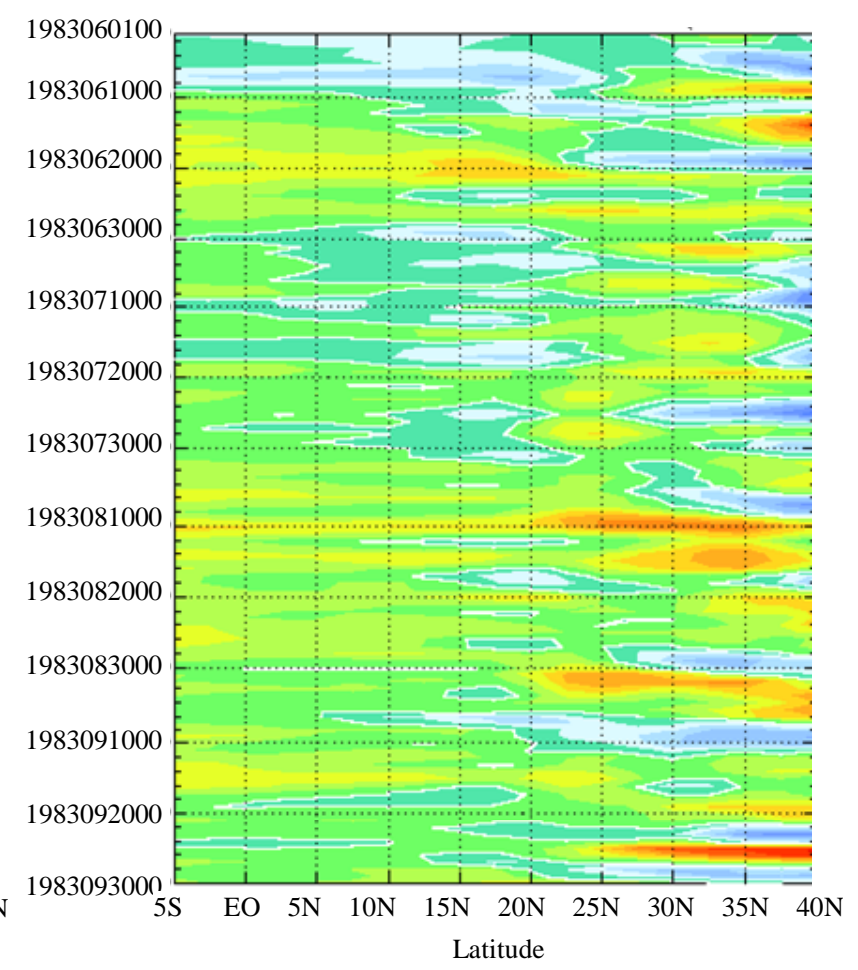

(b)

Figure 6. SLP anomalies (in Pascals), with respect the 1981-2010 mean, in the longitudinal band $5^{\circ} \mathrm{W}-15^{\circ} \mathrm{W}$ from $\mathrm{June}$ to September for the (a) 1975 wet year, and (b) 1983 the dry year (Data source: NOAA/ESRL/PSD).

June 1st to September 30th. It is seen that the negative SLP anomalies dominated the entire 1975 rainy season in contrast to the 1983 rainy season, that presented positive anomaly values up to $700 \mathrm{~Pa}$. In Figure 7, similar diagrams made for OLR anomalies $\left(\mathrm{W} / \mathrm{m}^{\wedge} \wedge 2\right)$ was plotted. The reader should recall that negative (positive) OLR anomaly values in tropical regions can be related to higher (lower) cloud tops, which, in turn, are associated with rainfall above (below) normal. Except for the beginning of June, it is apparent that negative anomalies up to $90 \mathrm{~W} / \mathrm{m}^{\wedge} 2$ dominated the latitudinal band $5^{\circ} \mathrm{N}-15^{\circ} \mathrm{N}$ during the 1975 wet season. On the other hand, only a few days in the 1983 wet season showed negative anomalies, being examples June 10th and September 10th. Both SLP and OLR anomalies diagrams are in agreement to each other and showed the pulsating character of the Western African monsoon. In other words, it seems that the FIT, i.e., the lower pressure area and the lower layer convergence, is present but rain events have to rely on pulses of moisture transport coming from the Atlantic Ocean. Sometimes these pulses are seen to travel northward of $20^{\circ} \mathrm{N}$ at speed of $3^{\circ}$ to $4^{\circ}$ latitude per day (Figure 7(a)). The vertical velocity omega $(\mathrm{Pa} / \mathrm{s})$ was plotted against latitude $\left(5^{\circ} \mathrm{S}-30^{\circ} \mathrm{N}\right)$, averaged in the $0^{\circ} \mathrm{W}-20^{\circ} \mathrm{W}$ longitudinal band for the wet season, for the 1975 wet year and 1983 dry year (Figure 8). The vertical dashed line was plotted at $12^{\circ} \mathrm{N}$ to help visualization. In the 1975 wet year, the omega values were more intense (Figure 8(a)) and extended farther north when compared to the 1983 dry year (Figure 8(b)). This indicates that the convective activity was deeper and FIT reached farther north in 1975. In Figure 8(b), the subsidence was stronger in the equator and northward of $24^{\circ} \mathrm{N}$ in 1983 , confirming what was observed in the SLP fields that a blocking pattern is established during dry years, obstructing the FIT movement northward. In the Figure 8(c) it was shown the difference between the wet and dry years, 1975 minus 1983. Again, it is obvious that convection was stronger and the FIT positioned farther north in 1975.

The West African region is influenced by the centers of subtropical high pressures of Azores (North Atlantic) and Santa Helena (South Atlantic), that control the seasonal oscillation of the marine trade winds, laden with moisture, and the dry continental winds blowing from northern Sahara Desert. In the interannual timescale, a quick inspection showed that, in the 1983 dry year, the northerly meridional component of the dry winds were more intense, reached $20^{\circ} \mathrm{N}$ at the surface and, in the average, dominated the layer 925 to $600 \mathrm{mb}$ as far south as the equator during the whole wet season. This vertical wind shear, certainly, reduced or inhibited the convective activity over Western Sahel. On the other hand, in the 1975 wet year, the meridional component of the moist southerly flow reached nearly $20^{\circ} \mathrm{N}$, suggesting the FIT 


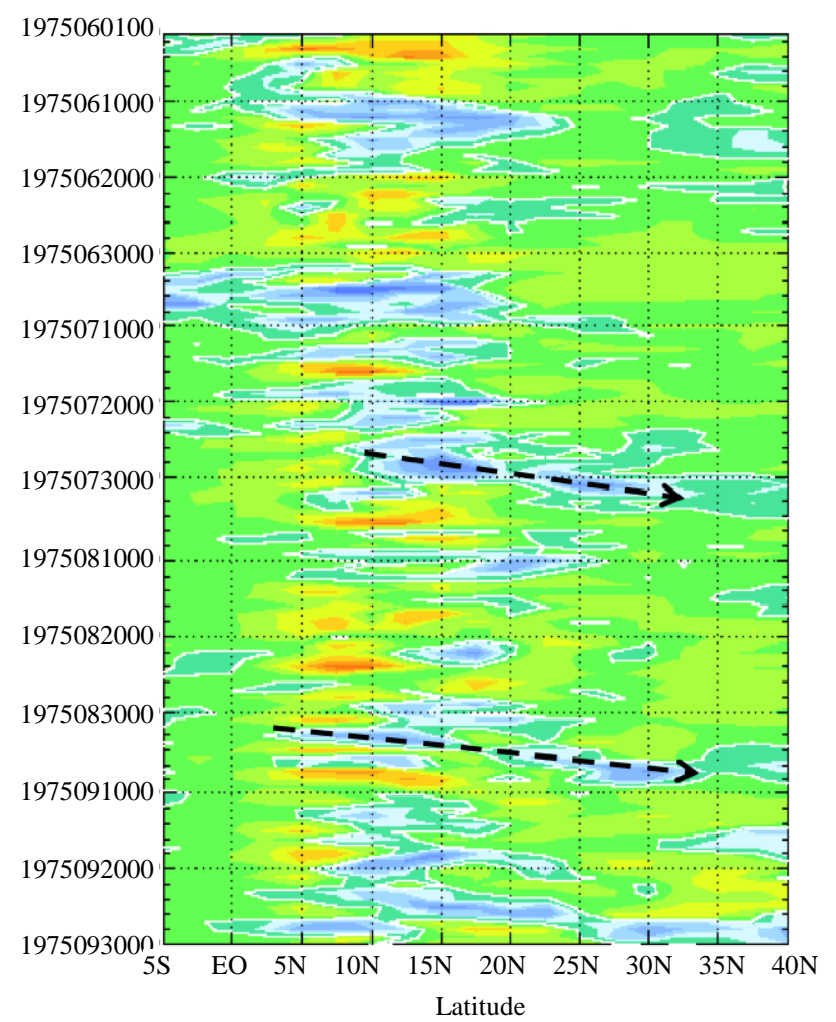

(a)

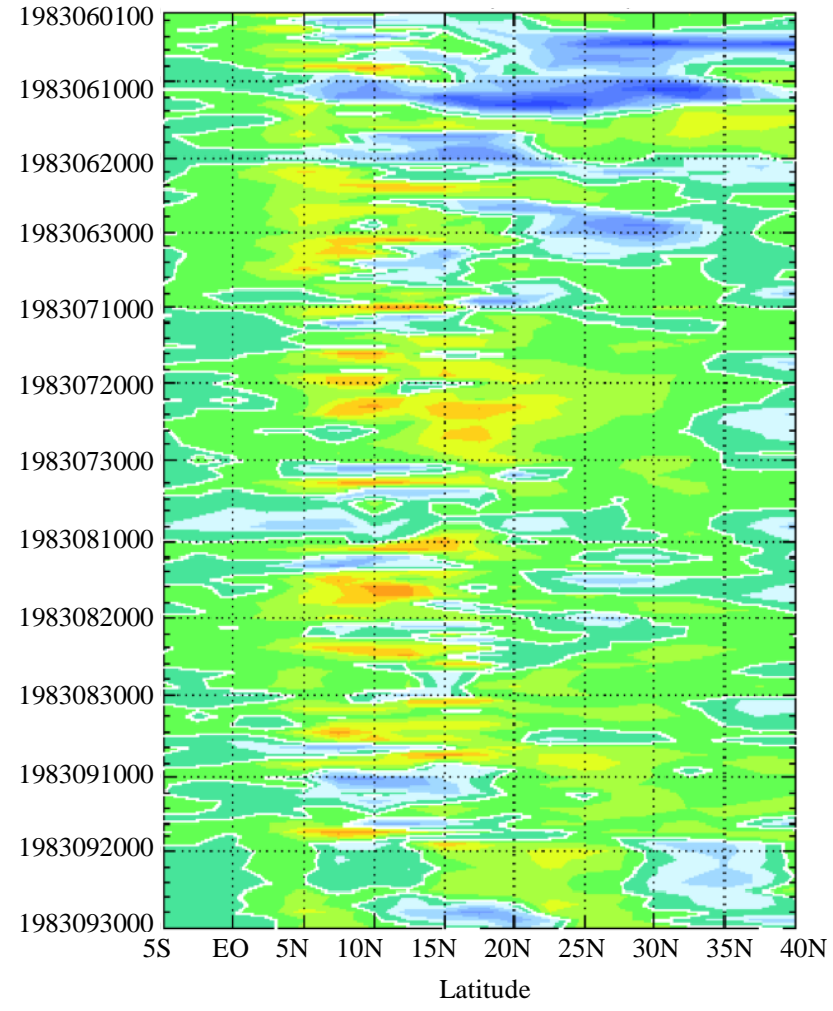

(b)

Figure 7. OLR anomalies (in $\mathrm{W} / \mathrm{m}^{\wedge} 2$ ), with respect the 1981-2010 mean, in the longitudinal band $5^{\circ} \mathrm{W}-15^{\circ} \mathrm{W}$ from $\mathrm{June}$ to September for the (a) 1975 wet year; and (b) 1983 dry year (Data source: NOAA/ESRL/PSD).

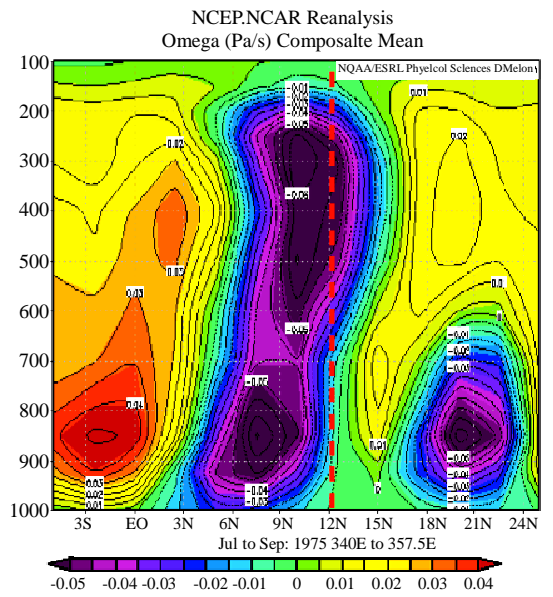

(a)

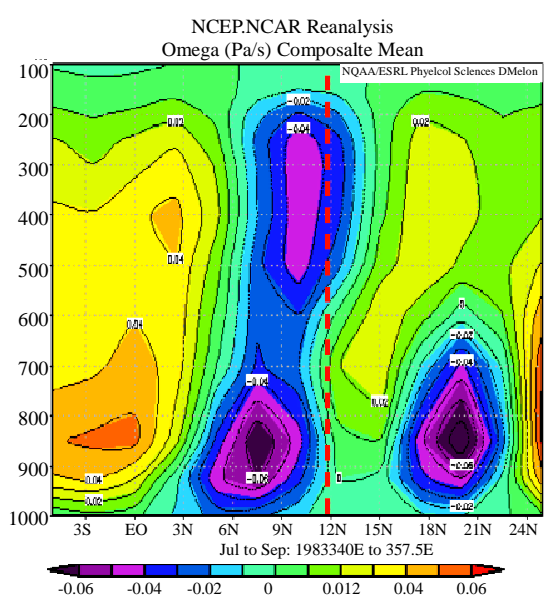

(b)

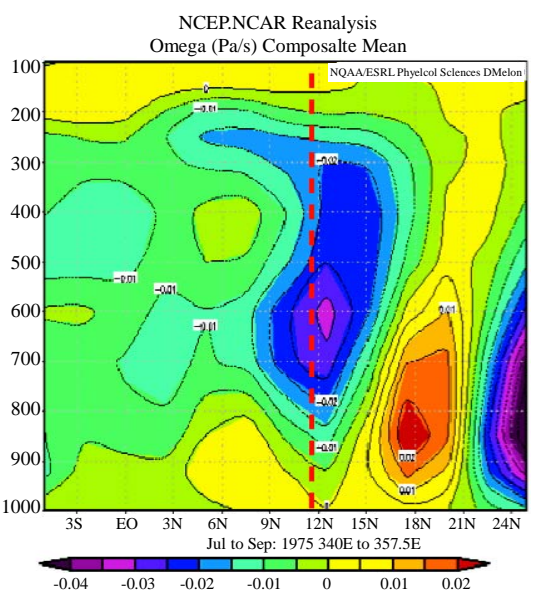

(c)

Figure 8. Latitudinal omega vertical velocity $(\mathrm{Pa} / \mathrm{s})$ section, averaged in the longitudinal band $0^{\circ} \mathrm{W}-20^{\circ} \mathrm{W}$ from $\mathrm{June}$ to September, for (a) the 1975 wet year; (b) for the 1983 dry year; and (c) the difference 1975 minus 1983 (Data source: NOAA/ ESRL/PSD).

displacement up to that latitude. In addition, the horizontal pressure gradient was lower in 1983, due to a slight increase in SLP over the equatorial Atlantic, reducing the moisture transport. In the decadal timescale, Rawson, as far back as 1907 (apud [32]), noticed that the Atlantic subtropical high pressure centers moved north-south (in fact, they move in southeasterly-northwesterly direction) with a near 19 years cycle and suggested that the centers motion could be related to the lunar nodal cycle, which is 18.6 years long. In response to the northward migration of the subtropical pressure centers, the FIT, and thus the Sahara's southern border, would move farther north. If 
the horizontal pressure gradient between south Atlantic high pressure system and the FIT becomes stronger, the moisture transport will be enhanced with a consequent period of abundant rainfall. The SLP analysis of the cold (1948-1976), during which the Sahel was wetter, and warm (1976-1998) phases of PDO, showed an enhancement (reduction) of the horizontal pressure gradient in the cold (warm) phase.

\section{Additional Comments}

Concern about desertification of the Sahelian environment arose in the early 1970s, when consecutive rainfall-deficient years culminated in the widespread Sahelian droughts of 1972 and 1973. As early as the mid1970s, it was postulated that the Sahel might be experiencing a shift to a generally more arid climatic regime [30]. Were the suggestions that the Sahel "drought" would end in 1985 [31] proved to be unfounded? During the 1980s, rainfall continued to be below the 1950s and 1960s. The years of 1983 and 1984 were extremely dry, with 1984 exhibiting the largest rainfall deficit of the twentieth century (30\% below the long-term mean). Rainfall remained below normal in 1985 and 1986 and the 1987 rainfall deficit was comparable to that of 1973 (20\% below the long-term mean). After the relatively wet year of 1988, rainfall anomalies were negative again till 1993, with rainfall totals in 1990 being comparable to those of 1987 and the mid-1970s. Rainfall in 1994 was similar to 1962 and was the largest aggregated total since the dry conditions onset. Years such as 1995 to 2000 were also dry, except 1998 rainfall that was above the long-term mean. Although 2000 rainfall totals were below the average, July and August were wet, with widespread floods in many Sahelian countries in August.

In the interannual timescale, it is generally accepted that drought in the Sahelian region is associated with interhemispheric SST gradient between the northern and southern tropical Atlantic Ocean. This hypothesis is used as a basis for seasonal climate forecasting schemes, but drought appears to be a consequence of shifts in the atmospheric circulation over the Sahelian region rather than SST primarily. Most of the moisture the feeds the ITF convective storms comes from the Guinea Gulf, whose SST presented a mean value above $25^{\circ} \mathrm{C}$ and slight increase (about $0.3^{\circ} \mathrm{C}$ ) from 1976 to 2000 relative to 1950 2000 period. The analysis performed here showed that the horizontal pressure gradient from the Guinea Gulf to the Sahel was reduced after 1976, thus weakening the trade winds and the moisture transport within the monsoon flow. This, in turn, reduced the number of rainstorms and the rainy season totals, as can be appreciated in Figures 6 and 7, that showed the pulsating character of convection within the ITF.
Did Sahel's rainfall recover lately? There are evidences that the region is "greening". But years 1998 to 2003 were evaluated using satellite estimates from TRMM whereas this analysis was performed with rain gauge data in previous years. Because of the switch from gauge to satellite, there is some spatial and temporal resolution problems and inhomogeneity in the analysis. Hence, the conclusion of the "greening" of the region has to be cautiously accepted. Nevertheless, the set of analyses performed point to some partial recovery.

\section{Conclusions}

This manuscript contains some additional useful information for understanding the rainfall variability and ITF role over the Western Sahel. The analysis was carried out in two steps: 1) The annual cycle and migration of the weather zones characterizing the climate of Western Africa were considered. This lead to evidence of a sudden and synchronous rain onset between $9^{\circ} \mathrm{N}$ and $13^{\circ} \mathrm{N}$, which did not follow the classic scheme of a north and south progressive migration of the rain zones with the sun; 2) The differences in the rainfall regimes between the two succeeding periods, 1950-1975 being wet and 1976-2000 being dry. The interannual rainfall difference between the wet and the dry periods is $180 \mathrm{~mm} / \mathrm{yr}$. This difference was relatively evenly distributed in space, with no clear meridional gradient. During the studied period, a systematic downward trend of the mean interannual rainfall was observed. The variations of the magnitude of the convective storms are, by contrast, smaller in amplitude and apparently randomly distributed in space. When looking at the intraseasonal timescale, it appears that the rainfall deficit of the dry period is primarily linked to a deficit of the number of rainstorm events occurring during the core of the rainy season over the Sahel, as can be seen in Figures 6 and 7, for instance. The SLP positive anomalies found after 1976, associated with warming of the Indian Ocean, may have inhibited convection development, thus reducing the rainstorm frequency. It was also shown that, farther south, the dry period was characterized by a shift in time of the second rainy season. All these characteristics have strong implications in terms of agricultural and water resources management. They also rose questions about the traditional scheme used to characterize the dynamics of the ITF and Western African monsoon flow.

The concern now is with the future of Sahel's climate. It is evident that Sahel climate variability is inextricably tied up to global climate variability, both in the interannual and the interdecadal timescales. It has been shown that Sahel's rainfall responds well to El Niño/La Niña events [24-29]. However, the response seems to be dependent on the interdecadal global climate variability. 
For instance, the La Niña events of the PDO cold phase were associated with abundant rainfall over Sahel as opposed to the El Niño events of the its warm phase that were related to the most severe drought observed during the studied period.

The cause of the Sahel's long-term rainfall variability is unclear and may be more than a single one. A quick correlation analysis performed with respect to the Atlantic Multidecadal Oscillation Indices (AMO), which is assumed to have 60 - 70 year cycle, did not render significant results. One possible reason, as stated before, is that most of the moisture that feeds the Western African monsoon flow comes from the Guinea Gulf. The AMO, on the other hand, reflects more the behavior of the extratropical North Atlantic Ocean, where the SST variability is more pronounced. Therefore, AMO would not have a sensible effect on the Sahel's climate. Is the Sahel's rainfall tied up with the PDO? It may be possible, since it seems that ENSO events, that have a significant impact in the region, are definitely related to PDO phases, as mentioned above. It is widely accepted that PDO entered a new cold phase since 1999-2000 and if it maintains its low frequency variability of 50 - 60 year cycle, each phase lasting 25 - 30 years, then it is expected that the rainfall totals, observed during the last cold phase (19461976), be reproduced again. However, the causes of the long-term rainfall variability may not be restricted to the air-sea interaction alone. Back in 1907, Rawson had noticed the north-south oscillatory character of the Atlantic subtropical high pressure centers in a nearly 19 year cycle, which affected rainfall in South Africa and Argentina [32]. He related this cycle to the Lunar nodal cycle of 18.6 years. Between the maximum and minimum, the Lunar nodal cycle changes the sea level height by \pm 6.5 $\mathrm{cm}$ in the North Atlantic and possibly the ocean current strength and its poleward heat transport, changing the global atmosphere lower boundary conditions and climate, since oceans cover $71 \%$ of Earth's surface. Recent lunar maxima occurred in 1950, 1968, 1987 and 2006, with minima in between every 9.3 years. If such an astronomical relationship exists and if the North Atlantic subtropical high pressure center started moving northward in 1996-1997, the rainfall in Sahel may improve in the next coming years. However, further work is necessary to detect such apparent cycles in the Sahel's climate.

It is expected that this work will help to interpreting Sahel's climate variability, contributing to seasonal climate prediction and the understanding of the possible impact of global climate change in the regional climate. Though rainfall may improve in the near future, man's action cannot be overruled, since land degradation in the Sahel itself may also be a contributing factor for local climate change, altering its heat and moisture budgets, a positive biogeophysical feedback proposed by [1].

\section{Acknowledgements}

P. S. Lucio was sponsored by a POCTI grant from FCT (Portugal), and at the present time he is sponsored by a PQ2 grant from CNPq (Brazil). C. E. A. Valadão is sponsored by CAPES (Brazil).

\section{REFERENCES}

[1] J. G. Charney, P. H. Stone and W. J. Quirk, "Drought in the Sahara: A Biogeophysical Feedback Mechanism," Science, Vol. 187, No. 4175, 1975, pp. 434-435. doi:10.1126/science.187.4175.434

[2] C. K. Folland, D. E. Parker and T. N. Palmer, "Sahel Rainfall and Worldwide Sea Temperatures 1901-1985,” Nature, Vol. 320, 1986, pp. 602-607. doi:10.1038/320602a0

[3] S. Janicot, V. Moron and B. Fontaine, "Sahel Droughts and Enso Dynamics," Geophysical Research Letters, Vol. 23, No. 5, 1996, pp. 515-518. doi:10.1029/96GL00246

[4] A. Giannini, R. Saravanan and P. Chang, "Ocean Forcing of Sahel Rainfall on Interannual to Interdecadal Time Scales,” Science, Vol. 302, No. 5647, 2003, pp. 10271030. doi:10.1126/science. 1089357

[5] L. Milich, "Expansion and Contraction of the Sahara Desert,” Science, Vol. 253, No. 5017, 1997, pp. 299-301.

[6] C. T. Agnew and A. Chappell, "Drought in the Sahel," GeoJournal, Vol. 48, No. 4, 2000, pp. 299-311. doi:10.1023/A:1007059403077

[7] T. Suzuki, "Seasonal Variation of the ITCZ and Its Characteristics over Central Africa," Theoretical and Applied Climatology, Vol. 103, No. 1-2, 2011, pp. 39-60.

[8] P. S. Lucio, L. C. B. Molion, E. Barai and F. Conde, "Saharian Desert Cyclic Events Based on Seasonal to Interannual Recurrent Sahel Rainfall Diagnosis,” Proceedings of 8 th International Conference on Southern Hemisphere Meteorology and Oceanography, Foz do Iguaçu, 24-28 April 2006, pp. 1483-1490.

[9] P. S. Lucio, L. C. B. Molion, F. C. Conde and M. L. D. de Melo, "A Study on the West Sahel Rainfall Variability: The Role of the Intertropical Convergence Zone (ITCZ),” African Journal of Agricultural Research, Vol. 7, No. 14, 2012, pp. 2096-2113.

[10] S. P. Harrison, D. Jolly, F. Laarif, A. Abe-Ouchi, B. Dong, K. Herterich, C. Hewitt, S. Joussaume, J. E. Kutzbach, J. Mitchell, N. de Noblet and P. Valdes, "Intercomparison of Simulated Global Vegetation Distribution in Response to 6 kyr BP Orbital Forcing," Journal of Climate, Vol. 11, No. 11, 1998, pp. 2721-2742. doi:10.1175/1520-0442(1998)011<2721:IOSGVD>2.0.C $\underline{\mathrm{O} ; 2}$

[11] R Development Core Team, "R: A Language and Environment for Statistical Computing," R Foundation for Statistical Computing, Vienna, 2009. http://www.R-project.org

[12] R. J. A. Little and D. B. Rubin, "Statistical Analysis with Missing Data,” John Wiley and Sons, New York, 1987.

[13] S. Van Buuren, J. P. L. Brand, C. G. M. Groothuis-Oud- 
shoorn and D. B. Rubin, "Fully Conditional Specification in Multivariate Imputation," Journal of Statistical Computation and Simulation, Vol. 76, No. 12, 2006, pp. 10491064. doi:10.1080/10629360600810434

[14] S. Van Buuren and K. Groothuis-Oudshoorn, "Mice: Multivariate Imputation by Chained Equations in R,” Journal of Statistical Software, Vol. 45, No. 3, 2011, pp. 1-67.

[15] G. R. McGregor and S. Nieuwolt, “Tropical Climatology: An introduction to the Climates of Low Latitudes," 2nd Edition, John Wiley \& Sons, Hoboken, 1998.

[16] S. Nicholson, "A Revised Picture of the Structure of the 'Monsoon' and Land ITCZ over West Africa," Climate Dynamics, Vol. 32, No. 7-8, 2009, pp. 1155-1171. doi:10.1007/s00382-008-0514-3

[17] D. E. Waliser and C. Gautier, "A Satellite-Derived Climatology of the ITCZ," Journal of Climate, Vol. 6, No. 11, 1993, pp. 2162-2174. doi:10.1175/1520-0442(1993)006<2162:ASDCOT >2.0.C $\underline{\mathrm{O} ; 2}$

[18] I. M. Lélé and P. J. Lamb, "Variability of the Intertropical Front (ITF) and Rainfall over the West African SudanSahel Zone,” Journal of Climate, Vol. 23, No. 14, 2010, pp. 3984-4004.

[19] S. Hastenrath, "Climate and Circulation of the Tropics (Atmospheric Sciences Library)," Springer, New York, 1985.

[20] M. Hulme, "Recent Climatic Change in the World's Drylands," Geophysical Research Letters, Vol. 23, No. 1, 1996, pp. 61-64. doi:10.1029/95GL03586

[21] T. B. McKee, N. J. Doesken and J. Kleist, "The Relationship of Drought Frequency and Duration to Time Scales,” Eighth Conference on Applied Climatology, Anaheim, 17-22 January 1993, pp. 179-184.

[22] P. Domonkos, “Application of Objective Homogenization Methods: Inhomogeneities in Time Series of Temperature and Precipitation,” Idojárás, Vol. 110, No. 1, 2006, pp. 63-87.

[23] D. P. Rowell and J. R. Milford, "On the Generation of African Squall Lines,” Journal of Climate, Vol. 6, No. 6, 1993, pp. 1181-1193. doi:10.1175/1520-0442(1993)006<1181:OTGOAS >2.0.C
$\underline{\mathrm{O} ; 2}$

[24] N. J. Mantua, S. R. Hare, Y. Zhang, J. M. Wallace and R. C. Francis, "A Pacific Interdecadal Climate Oscillation with Impacts on Salmon Production," Bulletin of the American Meteorological Society, Vol. 78, No. 6, 1997, pp. 1069-1079.

[25] C. A. Smith and P. Sardeshmukh, "The Effect of ENSO on the Intraseasonal Variance of Surface Temperature in Winter," International Journal of Climatology, Vol. 20, No. 13, 2000, pp. 1543-1557. doi:10.1002/1097-0088(20001115)20:13<1543::AID-JO C579>3.0.CO;2-A

[26] S. Nicholson, "An Overview of African Rainfall Fluctuations of the Last Decade,” Journal of Climate, Vol. 6, No. 7, 1993, pp. 1463-1466. doi:10.1175/1520-0442(1993)006<1463:AOOARF $>2.0 . C$ $\underline{\mathrm{O} ; 2}$

[27] S. Nicholson and J. Kim, "The Relationship of the El Niño Southern Oscillation to African Rainfall,” International Journal of Climatology, Vol. 17, No. 2, 1997, pp. 117-135. doi:10.1002/(SICI)1097-0088(199702)17:2<117::AID-JO C84>3.0.CO;2-O

[28] S. Nicholson, "The Natureof Rainfall Variability over Africa on Time Scales of Decades to Millennia,” Global and Planetary Change, Vol. 26, No. 1-3, 2000, pp. 137-158. doi:10.1016/S0921-8181(00)00040-0

[29] S. Nicholson, "On the Question of the 'Recovery' of the Rains in the West African Sahel," Journal of Arid Environment, Vol. 63, No. 3, 2005, pp. 615-641. doi:10.1016/j.jaridenv.2005.03.004

[30] T. J. Kelly, "Climate and the West African Drought," In: J. L. Newman, Ed., Drought, Famine and Population Movements in Africa, Syracuse University, New York, 1975, pp. 14-31.

[31] H. Faure and J.-Y. Gac, "Will the Sahelian Drought End in 1985?” Nature, Vol. 291, 1981, pp. 475-478. doi:10.1038/291475a0

[32] H. H. Lamb, "Climate: Present, Past and Future. Volume 1: Fundamentals and Climate Now,” Methuen \& Co. Ltd., London, 1972. 